\title{
Cytotoxic metabolites from Thysanolaena maxima Roxb. available in Bangladesh
}

\author{
Nazia Hoque ${ }^{1,2,3}$, Md. Hossain Sohrab ${ }^{2 *}$, Farhana Afroz ${ }^{2}$, Satyajit Roy Rony ${ }^{2}$, Suriya Sharmin², Fatema Moni ${ }^{2}$, \\ Choudhury Mahmood Hasan ${ }^{4}$ and Md. Sohel Rana ${ }^{3}$
}

\begin{abstract}
Background: Thysanolaena maxima (Roxb.) Kuntze, a perennial grass plant, is usually distributed in hilly regions of the Indian Subcontinent. Different parts of T. maxima have been used as herbal medicine by traditional healers of this region. In this present study, T. maxima plant extract has been screened for examination of its secondary metabolite content with their probable cytotoxic activity.

Methods: Secondary metabolites of the crude T. maxima plant extract were isolated by different chromatographic methods. The structures were elucidated by spectroscopic data $\left({ }^{1} \mathrm{H} N \mathrm{NMR},{ }^{13} \mathrm{C}\right.$ NMR) as well as comparison with available literature sources. Antiradical activity by DPPH radical scavenging assay and antimicrobial activity by disc diffusion method of the fractions and cytotoxic activity by trypan blue exclusion method of the isolated compounds were also evaluated.
\end{abstract}

Results: Three phenolic compounds 4-hydroxybenzaldehyde (1), 4-hydroxycinnamic acid (2), 4-hydroxybenzoic acid (3) and two steroids stigmast-4-en-3-one (4) and $\beta$-stigmasterol (5) were isolated from the aerial part of T. maxima. Among the compounds 4-hydroxycinnamic acid, 4-hydroxybenzoic acid and stigmast-4-en-3-one exhibited notable cytotoxic activity against African Green Monkey Kidney Cell line (Vero cell).

Conclusion: Bioassay investigation of the isolated compounds and fractions suggested that T. maxima could be a potential source of bioactive secondary metabolites.

Keywords: Thysanolaena maxima, Antiradical activity, Antimicrobial activity, Cytotoxicity, Stigmast-4-en-3-one

\section{Background}

Thysanolaena maxima (Roxb.), Kuntze (Family: Poaceae) (Synonym: Thysanolaena latifolia, English name: Tiger grass), a perennial forest grass plant, is found in the hilly regions of Bangladesh, India, Thailand, Nepal and Bhutan. Many tribal populations of these countries have been using different parts of this plant traditionally for many years. The inflorescence paste of $T$. maxima was used for the treatment of eye infection by traditional healers of Meghalaya, India [1]. Soft part of young leaves and flower buds are used as raw form to cure flatulence

\footnotetext{
* Correspondence: mhsohrab@bcsir.gov.bd

${ }^{2}$ Pharmaceutical Sciences Research Division, BCSIR Laboratories Dhaka, Bangladesh Council of Scientific and Industrial Research (BCSIR), Dr.

Qudrat-I-Khuda Road, Dhanmondi, Dhaka 1205, Bangladesh

Full list of author information is available at the end of the article
}

and improve digestion by Dimasa tribes of Assam in India [2]. Young shoots and fresh roots are used in the treatment of tonsillitis, boils and skin diseases by the people of Darjeeling district, West Bengal, India [3]. Crushed flowers are taken with water as antiemetic and in the treatment of stomach trouble by Kanda tribal population of Sylhet in Bangladesh [4]. It has also been reported to be useful as anthelmintic and febrifuge by the local people of Sabah, Malaysia [5].

Pharmacological studies have demonstrated that ethanol extract of T. maxima roots possessed moderate DPPH radical scavenging activity $\left(\mathrm{IC}_{50}\right.$ value: $\left.250 \mu \mathrm{g} / \mathrm{ml}\right)$ and antibacterial activity against four bacterial strains [6]. Aqueous extract of T. maxima showed significant chemopreventive and hepatoprotective activity against $\mathrm{CCl}_{4}$ induced hepatotoxicity in rats [5]. Furthermore,

\section{Springer Open}

() The Author(s). 2020 Open Access This article is licensed under a Creative Commons Attribution 4.0 International License, which permits use, sharing, adaptation, distribution and reproduction in any medium or format, as long as you give appropriate credit to the original author(s) and the source, provide a link to the Creative Commons licence, and indicate if changes were made. The images or other third party material in this article are included in the article's Creative Commons licence, unless indicated otherwise in a credit line to the material. If material is not included in the article's Creative Commons licence and your intended use is not permitted by statutory regulation or exceeds the permitted use, you will need to obtain permission directly from the copyright holder. To view a copy of this licence, visit http://creativecommons.org/licenses/by/4.0/. 
ethanolic extract of leaves of $T$. maxima showed cytotoxic activity against HepG2 cancer cell line where the percentage inhibition was $29.50 \pm 3.9$ at the concentration of $50 \mu \mathrm{g} / \mathrm{ml}$ [3]. The bioactivities of the different solvent extract of $T$. maxima have evidenced it as a potent source of natural radical scavenger [7]. Few compounds have been successfully isolated from the florets of $T$. maxima in Nepal such as luteolin, isoswertisin, isoquercetin, ergosterol peroxide, $\beta$-sitosterol, $7 \alpha$-hydroxysitosterol, benzoicacid, syringic acid, leonuriside $\mathrm{A}, 7 R$, 8R-4-O-methylsyringylglycerol, butyl protocatechuate, jaboticabin acid, caffeic anhydride etc. [8]. For the established traditional use of this plant as herbal medicine by different tribal populations and for its distinguished pharmacological activities, it is, therefore, indispensable to separate and characterize its chemical constituents in terms of functionality. Therefore, the objective of this investigation was to isolate the metabolites produced by T. maxima available in Bangladesh and to assess the antiradical, antimicrobial and cytotoxic activity of the fractions and their isolated compounds.

\section{Materials and methods}

Apparatus and reagents

2,2-Diphenyl-1-picrylhydrazyl (DPPH) was purchased from Sigma-Aldrich Co., USA. Silica gel and silica gel $\mathrm{F}_{254}$ plates were purchased from Merck, Germany. $\mathrm{Nu}-$ trient agar media, standard disc of kanamycin and ketoconazole were purchased from $\mathrm{Hi}$ media, India. The NMR spectra were documented by $400 \mathrm{MHz}$ NMR spectrometer (Bruker, Switzerland) using deuterated chloroform and deuterated methanol purchased from Sigma-Aldrich Co., USA. All the chemicals and solvents used were of analytical grades.

\section{Plant collection and identification}

The aerial part of $T$. maxima was collected from Rangamati, Chittagong Hill Tracts, Bangladesh on August 20, 2015. The taxonomical identification of the tested plant was authenticated from Bangladesh National Herbarium (BNH), Mirpur, Dhaka and voucher specimen was deposited in the $\mathrm{BNH}$ with the accession number DACB 42267.

\section{Preparation of the crude extract}

A total of $1 \mathrm{~kg}$ powdered coarse plant materials were subjected to maceration in dichloromethane:methanol (1: 1) mixture using $2.5 \mathrm{l}$ of each solvent in an air-tight container for 5 days with intermittent shaking. The solvent mixture with most of the extractable compounds was collected by filtration with cotton plug followed by filter paper. The solvent was removed using rotary evaporator (Heidolph, Germany) at temperature around $40^{\circ} \mathrm{C}$ $50^{\circ} \mathrm{C}$ under reduced pressure. The above process was repeated two times with fresh solvents to gather more concentrated extract. Finally, all the filtrates were mixed together to get the crude extract $(19 \mathrm{~g})$.

\section{Chromatographic procedures}

The crude extract was fractionated by vacuum liquid chromatography (VLC) on silica gel (60G) eluted with gradient solvent system as petroleum ether- $\mathrm{CH}_{2} \mathrm{Cl}_{2}$ $\mathrm{MeOH}$ to obtain 27 fractions. These fractions were screened by thin layer chromatography (TLC) with aluminum plates coated with silica gel $\left(\mathrm{F}_{254}\right)$ and the plates were envisaged under UV light at $254 \mathrm{~nm}, 365 \mathrm{~nm}$ and by spraying with vanillin/1\% $\mathrm{H}_{2} \mathrm{SO}_{4}$ solution followed by heating. The fractions having similar TLC patterns were combined to give 8 fractions (F-1 to F-8). Column chromatography (silica gel 70-230 and 230-400, mesh) and preparative TLC (PTLC) were performed for separation and purification of the compounds from the VLC fractions.

\section{Bioassay screening of the fractions DPPH free radical scavenging activity}

The free radical scavenging ability of T. maxima VLC fractions were screened by measuring the reduced absorbance of methanolic DPPH solution [9]. Methanolic DPPH stock solution $(20 \mu \mathrm{g} / \mathrm{mL})$ was added $(200 \mu \mathrm{L})$ to methanolic sample solution to obtain final $4 \mathrm{ml}$ solution of different concentration $(200 \mu \mathrm{g} / \mathrm{mL}$ to $12.5 \mu \mathrm{g} / \mathrm{mL})$. The absorbance was measured at $517 \mathrm{~nm}$ by using UVVIS spectrophotometer (Analytic Jena AG, Germany) after the solutions were mixed properly and kept in dark for $20 \mathrm{~min}$. The result was expressed using the following formula as the percentage inhibition:

$$
\left[\left(\mathrm{A}_{0}-\mathrm{A}_{1}\right) / \mathrm{A}_{0}\right] \mathrm{x} 100
$$

where $A_{0}$ is the absorbance of the control and $A_{1}$ is the absorbance of the fractions/standard.

\section{Antimicrobial assay}

Disc diffusion method was used for preliminary antimicrobial assay [10] against four bacterial strains (Bacillus megaterium, Staphylococcus aureus, Pseudomonas aeruginosa and Escherichia coli) and two fungal strains (Aspergillus flavus and Aspergillus niger). A total of $100 \mu \mathrm{L}$ of suspension of each microorganism containing approximately $100-150 \mathrm{CFU} / \mathrm{mL}$ was spread over the nutrient agar for bacteria and potato dextrose agar media for fungi. Filter paper discs around $6 \mathrm{~mm}$ diameter were sterilized, steeped with $200 \mu \mathrm{g}$ of different fraction solutions and placed gently in the spreaded agar plates. Kanamycin $(30 \mu \mathrm{g} / \mathrm{disc})$ and ketoconazole $(30 \mu \mathrm{g} / \mathrm{disc})$ were used as positive control and solvent discs were used as negative control in this study. The zone of 
inhibition was measured as diameter in $\mathrm{mm}$ after 24-h incubation at $37^{\circ} \mathrm{C}$ for bacteria and 48 -h incubation at $28{ }^{\circ} \mathrm{C}$ for fungi.

\section{Isolation of the compounds}

Phytochemical investigation for compound isolation on fractions F-2, F-3 and F-4 were performed based on the preliminary chemical profiling using TLC, antimicrobial activity of F-2 and F-3 and antiradical activity of F-4. Polar fractions F-5 to F-8 eluted with $\mathrm{CH}_{2} \mathrm{Cl}_{2} / 0.1-8 \%$ $\mathrm{MeOH}$ showed very poor resolution of the compounds on TLC due to matrix effect. Therefore, phytochemical investigation for isolation of compounds from fraction F-5 to F-8 could not carry out in spite of their strong antiradical property.

An aliquot $(80 \mathrm{mg})$ of VLC fraction F-3 (583.4 mg) eluted with petroleum ether/35-45\% $\mathrm{CH}_{2} \mathrm{Cl}_{2}$ was subjected to preparative thin layer chromatography (PTLC) (stationary phase: silica gel $\mathrm{F}_{254}$, mobile phase: toluene/ 10\% EtOAc, two developments; thickness of plates: 0.25 $\mathrm{mm}$ ) to afford compound $\mathbf{1}$ (3.0 mg, 3.75\%). Compound 2 (2.5 mg, 3.12\%) was obtained by subjecting $80 \mathrm{mg}$ of the VLC fraction F-4 (1.38 g) eluted with petroleum ether/50-85\% $\mathrm{CH}_{2} \mathrm{Cl}_{2}$ to PTLC (mobile phase: toluene/ $30 \%$ EtOAc, 2 developments). Fraction F-3 was subjected to silica gel column chromatography and eluted with $n$ hexane- $\mathrm{CH}_{2} \mathrm{Cl}_{2}-\mathrm{MeOH}$ solvent system with increasing polarity. Column fraction eluted with $n$-hexane/35-40\% $\mathrm{CH}_{2} \mathrm{Cl}_{2}$ gave brown amorphous mass which was purified by solvent treatment to afford compound 3 (2.2 $\mathrm{mg}$, $2.75 \%$ ). Fraction F-4 was rechromatographed by silica gel column chromatography eluted with petroleum ether- $\mathrm{CH}_{2} \mathrm{Cl}_{2}-\mathrm{MeOH}$ in gradients of increasing polarities. Fraction obtained by petroleum ether/85-95\% $\mathrm{CH}_{2} \mathrm{Cl}_{2}$ was further purified by PTLC (mobile phase: toluene/5\% EtOAc, 2 developments) to yield compound 4 (3.0 $\mathrm{mg})$. One slightly impure white crystal obtained from the VLC fraction of petroleum ether/ 20-30\% $\mathrm{CH}_{2} \mathrm{Cl}_{2}$ (F-2, $287.5 \mathrm{mg}$ ) was purified by treatment with different solvents to get compound 5 (3.2 mg, 4\%).

4-Hydroxybenzaldehyde (1): (3.0 mg, brown amorphous powder); ${ }^{1} \mathrm{H}$ NMR $\left(400 \mathrm{MHz}, \mathrm{CDCl}_{3}\right): \delta$ $9.78(1 \mathrm{H}, \mathrm{s},-\mathrm{CHO}), 7.74(2 \mathrm{H}, \mathrm{d}, J=8.6 \mathrm{~Hz}, \mathrm{H}-2, \mathrm{H}-6)$, $6.91(2 \mathrm{H}, \mathrm{d}, J=8.6 \mathrm{~Hz}, \mathrm{H}-3, \mathrm{H}-5) .{ }^{13} \mathrm{C}$ NMR $(100 \mathrm{MHz}$, $\left.\mathrm{CDCl}_{3}\right): \delta 191.4(-\mathrm{CHO}), 163.2(\mathrm{C}-4), 132.4$ (C-2, C-6), 128.8 (C-1), 115.8 (C-3, C-5).

4-Hydroxycinnamic acid (2): (2.5 mg, white amorphous powder); ${ }^{1} \mathrm{H}$ NMR $\left(400 \mathrm{MHz}, \mathrm{CDCl}_{3} / 1 \%\right.$ $\left.\mathrm{CD}_{3} \mathrm{OD}\right): \delta 7.37(2 \mathrm{H}, \mathrm{d}, J=8.2 \mathrm{~Hz}, \mathrm{H}-2, \mathrm{H}-6), 6.79(2 \mathrm{H}$, d, $J=8.2 \mathrm{~Hz}, \mathrm{H}-3, \mathrm{H}-5), 7.60(1 \mathrm{H}, \mathrm{d}, J=16.0 \mathrm{~Hz}, \mathrm{H}-7)$, $6.23(1 \mathrm{H}, \mathrm{d}, J=16.0 \mathrm{~Hz}, \mathrm{H}-8) .{ }^{13} \mathrm{C}$ NMR $(100 \mathrm{MHz}$,
$\left.\mathrm{CDCl}_{3}\right): \delta 169.3$ (C-9), 158.8 (C-4), 145.3 (C-7),132.0

(C-2, C-6), 125.9 (C-1), 115.5 (C-3, C-5), 114.6 (C-8).

4-Hydroxybenzoic acid (3): (2.2 mg, brown amorphous powder); ${ }^{1} \mathrm{H}$ NMR (400 $\left.\mathrm{MHz}, \mathrm{CD}_{3} \mathrm{OD}\right): \delta$ $7.88(2 \mathrm{H}, \mathrm{d}, J=8.4 \mathrm{~Hz}, \mathrm{H}-2, \mathrm{H}-6), 6.78(2 \mathrm{H}, \mathrm{d}, J=8.4$ $\mathrm{Hz}, \mathrm{H}-3, \mathrm{H}-5) .{ }^{13} \mathrm{C}$ NMR $\left(\mathrm{CD}_{3} \mathrm{OD}, 100 \mathrm{MHz}\right): \delta 171.4$ (-COOH), 163.2 (C-4), 132.4 (C-2, C-6), 128.9 (C-1), 115.8 (C-3, C-5).

Stigmast-4-en-3-one (4): (3 mg, white crystal); ${ }^{1} \mathrm{H}$ NMR (400 MHz, $\left.\mathrm{CDCl}_{3}\right): \delta 5.75(1 \mathrm{H}, \mathrm{s}, \mathrm{H}-4), 1.20(3 \mathrm{H}$, s, H-19), $0.94(3 \mathrm{H}, \mathrm{d}, J=5.2 \mathrm{~Hz}, \mathrm{H}-21), 0.91(3 \mathrm{H}, \mathrm{d}, J=$ 6.4 Hz, H-29), 0.87 (3H, d, $J=5.6 \mathrm{~Hz}, \mathrm{H}-26), 0.84(3 \mathrm{H}$, $\mathrm{d}, J=5.6 \mathrm{~Hz}, \mathrm{H}-27), 0.73(3 \mathrm{H}, \mathrm{s}, \mathrm{H}-18) .{ }^{13} \mathrm{C}$ NMR (100 $\mathrm{MHz}, \mathrm{CDCl}_{3}$ ): $\delta 198.9$ (C-3), 171.4 (C-5), 123.6 (C-4), 55.9 (C-17), 55.8 (C-14), 53.7 (C-9), 45.7 (C-24), 42.5 (C-13), 39.7 (C-12), 38.6 (C-10), 36.0 (C-20), 35.7 (C8), 35.6 (C-1), 34.0 (C-22), 33.9 (C-2), 32.9 (C-6), 32.1 (C-7), 29.1 (C-25), 28.1 (C-16), 26.1 (C-23), 24.1 (C15), 23.1 (C-28), 21.1 (C-11), 19.7 (C-26), 19.1 (C-27), 18.7 (C-21), 17.5 (C-19), 11.9 (C-18), 11.9 (C-29).

$\boldsymbol{\beta}$-stigmasterol (5): (3.2 mg, white needle); ${ }^{1} \mathrm{H}$ NMR $\left(400 \mathrm{MHz}, \mathrm{CDCl}_{3}\right): \delta 5.37(1 \mathrm{H}, \mathrm{d}, J=4.8 \mathrm{~Hz}, \mathrm{H}-6), 5.18$ $(1 \mathrm{H}, \mathrm{dd}, J=15.0,8.6 \mathrm{~Hz}, \mathrm{H}-22), 5.04(1 \mathrm{H}, \mathrm{dd}, J=15.2$, 8.4 Hz, H-23), 3.55 (1H, m, H-3), 1.03 (3H, s, H-19), $0.94(3 \mathrm{H}, \mathrm{d}, J=6.4 \mathrm{~Hz}, \mathrm{H}-21), 0.86(3 \mathrm{H}, \mathrm{d}, J=2.8 \mathrm{~Hz}$, H-29), 0.85 (3H, d, $J=1.2 \mathrm{~Hz}, \mathrm{H}-26), 0.82$ (3H, d, $J=$ $7.2 \mathrm{~Hz}, \mathrm{H}-27), 0.71$ (3H, s, H-18). ${ }^{13} \mathrm{C}$ NMR (100 MHz, $\left.\mathrm{CDCl}_{3}\right): \delta 140.7(\mathrm{C}-5), 138.4(\mathrm{C}-22), 129.2$ (C-23), 121.6 (C-6), 71.8 (C-3), 56.9 (C-14), 56.8 (C-17), 51.2 (C-24), 50.1 (C-9), 45.8 (C-25), 42.3 (C-13), 42.2 (C-4), 40.4 (C-20), 39.8 (C-12), 37.2 (C-1), 36.4 (C-10), 33.9 (C-8), 31.7 (C-7), 29.2 (C-16), 28.1 (C-2), 24.4 (C-28), 24.3 (C-15), 21.1 (C-11), 21.0 (C-21), 19.7 (C-27), 19.3 (C26), 19.0 (C-19), 12.1 (C-29), 12.0 (C-18).

\section{Evaluation of cytotoxicity of pure compounds}

Cytotoxic activity was studied against Vero cell line (Vero cell line, CLS 605372, Germany) using slight modification of the Trypan Blue Exclusion Method [11, 12]. Cells were cultivated in $75 \mathrm{~cm}^{2}$ flasks in $5 \%(\mathrm{v} / \mathrm{v})$ $\mathrm{CO}_{2}$ at $37^{\circ} \mathrm{C}$ with media described at Khan et al, 2018 [10]. According to study design, cells were grouped into 3 with three replica each. Treatment groups were evaluated with vehicle group. Vero cells were split the day before experiments. The freshly prepared doses $(0.1$, $0.5,1.0,5.0,10$ and $20 \mu \mathrm{g} / \mathrm{mL}$ ) were administered into 1 day before cultured T- flasks with approximately $2.5 \times$ $10^{6}$ cells. Negative control corresponds to the cells cultured with medium with $0.6 \%$ DMSO. After $24 \mathrm{~h}$ of incubation period cells were harvested using $0.5 \%$ trypsin. The number of dead cells was calculated by automated cell counter (LUNA-II ${ }^{\mathrm{TM}}$, South Korea) [13] using trypan blue $(0.4 \% \mathrm{w} / \mathrm{v})$. Percentage of dead cells was calculated following the mathematical formula: 
Percentage of dead cells $=\frac{\text { No of stained }(\text { dead }) \text { cells }}{\text { Total number of cells }} \times 100$

\section{Statistical analysis}

All values for antioxidant and antimicrobial evaluation were determined as mean \pm standard deviation (SD) where $n=3$. Continuous variables between groups were compared with one-way analysis of variance (ANOVA) with post hoc tukey's test for the analysis of the cytotoxicity results of pure compounds. Mean values between groups were compared using independent student t-test for equality of variances. Statistical significance was accepted when $P<0.001$.

\section{Results}

Bioassay screening of fractions

$D P P H$ free radical scavenging activity

The DPPH free radical scavenging method was exercised to investigate the antiradical activity of the fractions. Fraction F-7 exhibited the highest antiradical scavenging activity $\left(\mathrm{IC}_{50}=21.39 \pm 2.02 \mu \mathrm{g} / \mathrm{mL}\right)$ whereas $\mathrm{F}-1$ showed the lowest activity $\left(\mathrm{IC}_{50}=149.68 \pm 1.91 \mu \mathrm{g} / \mathrm{mL}\right)$ (Table 1$)$. The values of scavenging activity which denotes as $\mathrm{IC}_{50}$ of the fractions with standard (ascorbic acid) are shown in Table 1. The results indicated that fractions F-3 to F8 possess antioxidant compounds that may play a significant role to prevent diseases caused by reactive oxygen species.

\section{Antimicrobial assay}

The antimicrobial activity of the fractions and the standards against different microorganisms is shown in Table 2. The fractions $(200 \mu \mathrm{g} / \mathrm{disc})$ showed weak to strong activities against some test microorganisms compared to the standard discs. Fraction F-3 exhibited notable antifungal activity against Aspergillus niger (19.3 \pm $1.1 \mathrm{~mm}$ ) and antibacterial activity against Bacillus megaterium $(12.0 \pm 0.5 \mathrm{~mm})$ (Table 2). Fraction F-2 showed

Table $1 \mid C_{50}$ values of fractions of T. maxima and ascorbic acid

\begin{tabular}{ll}
\hline Fraction/ standard & $\mathbf{I C}_{\mathbf{5 0}}$ values $(\boldsymbol{\mu g} / \mathbf{m L})$ \\
\hline F1 & $149.68 \pm 1.91$ \\
F2 & $101.02 \pm 3.14$ \\
F3 & $80.26 \pm 5.65$ \\
F4 & $60.31 \pm 3.57$ \\
F5 & $49.70 \pm 1.71$ \\
F6 & $26.56 \pm 1.39$ \\
F7 & $21.39 \pm 2.02$ \\
F8 & $35.90 \pm 5.49$ \\
Ascorbic acid & $4.26 \pm 0.17$ \\
\hline
\end{tabular}

Values are represented as mean \pm standard deviation $(n=3)$ antibacterial activity against three bacterial strains $(\mathrm{Ba}$ cillus megaterium, Pseudomonas aeruginosa and Escherichia coli) but found to be inactive against tested fungal strains. Other fractions (F-1, F-4 to F-8) were failed to present antimicrobial activity against the tested microorganisms.

\section{Secondary metabolites from Thysanolaena maxima}

Compounds $\mathbf{1}$ - $\mathbf{5}$ were isolated from dichloromethane: methanol (1:1) extract of $T$. maxima using different chromatographic methods. The structures of these compounds were elucidated by comparing their NMR data with those in the related literature (Fig. 1). To the best of our knowledge, compounds $\mathbf{1}, \mathbf{2}, \mathbf{4}$ and $\mathbf{5}$ were isolated from T. maxima for the first time.

Compound $\mathbf{1}$ was obtained as brown amorphous solid. The ${ }^{1} \mathrm{H}$ NMR spectrum of compound 1 showed two doublets at $\delta 7.74$ and $\delta 6.91 \mathrm{ppm}$ characteristic of a para disubstituted aromatic compound and a signal for an aldehydic proton at $\delta 9.78 \mathrm{ppm}$. The ${ }^{13} \mathrm{C} \mathrm{NMR}$ showed one aldehydic carbon at $\delta 191.4 \mathrm{ppm}$, one oxygenated carbon signal at $\delta 163.2 \mathrm{ppm}$ and four olefins at $\delta 132.4$ and $115.8 \mathrm{ppm}$. These spectroscopic data are found to be identical with the spectroscopic data of 4hydroxybenzaldehyde [14].

Compound 2 was obtained as white amorphous solid. The ${ }^{1} \mathrm{H}$ NMR spectrum of compound 2 displayed proton signals at $\delta 7.37$ and $\delta 6.79 \mathrm{ppm}$ and two trans-olefinic proton signals at $\delta 7.60$ and $\delta 6.23 \mathrm{ppm}$. The ${ }^{13} \mathrm{C}$ NMR spectrum of compound 2 showed nine signals corresponding to one carboxylic acid signal at $\delta 169.3 \mathrm{ppm}$, one oxygenated quaternary carbon signal at $\delta 158.8$ ppm, and six methine carbon signals at $\delta$ 132.0, 115.5, 145.3 and $114.6 \mathrm{ppm}$. Thus, compound 2 was identified as 4-hydroxycinnamic acid by comparing these data with the reported values [15].

Compound 3 was obtained as brown amorphous solid. The ${ }^{1} \mathrm{H}$ NMR spectrum of compound 3 showed orthocoupled proton signals at $\delta 7.88$ and $\delta 6.78 \mathrm{ppm}$. The ${ }^{13} \mathrm{C}$ NMR of compound 3 contained one carboxyl carbon signal at $\delta 171.4 \mathrm{ppm}$, one oxygenated carbon signal at $\delta 163.2 \mathrm{ppm}$, and four methine carbon signals at $\delta$ 132.4 and $\delta 115.8 \mathrm{ppm}$. According to this analysis and compared with published spectroscopic data [14], compound 3 was suggested as 4-hydroxybenzoic acid.

Compound $\mathbf{4}$ was obtained as white crystals. The ${ }^{1} \mathrm{H}$ NMR spectrum of compound $\mathbf{4}$ showed one-proton singlet in the olefinic region at $\delta 5.75 \mathrm{ppm}$, two singlets at $\delta 0.73$ and $1.20 \mathrm{ppm}$ and four three proton doublets at $\delta 0.94,0.87,0.84$ and $0.91 \mathrm{ppm}$. The presence of 29 carbons in the molecule clearly indicated by the 29 signals in the ${ }^{13} \mathrm{C}$ NMR spectrum including a carbonyl peak at $\delta 198.9 \mathrm{ppm}$ and two olefinic carbon peaks at $\delta 123.6$ and $\delta 171.4 \mathrm{ppm}$. These spectral 
Table 2 Zone of inhibition of different fractions of T. maxima, kanamycin and ketoconazole

\begin{tabular}{|c|c|c|c|c|c|c|c|c|c|}
\hline $\begin{array}{l}\text { Name of the } \\
\text { microorganisms }\end{array}$ & $\begin{array}{l}\mathrm{F}-1 \\
(200\end{array}$ & \multicolumn{6}{|c|}{ (200 $\mu \mathrm{g} / \mathrm{disc})$} & $\mathrm{F}-8$ & $\begin{array}{l}\text { Kanamycin, ketoconazole } \\
\text { (30 } \mu \mathrm{g} / \text { disc) }\end{array}$ \\
\hline \multicolumn{10}{|l|}{ Zone of inhibition (mm) } \\
\hline Bacillus megaterium & - & $12.0 \pm 0.5$ & $12.0 \pm 0.5$ & - & - & - & - & - & $30.0 \pm 0.5$ \\
\hline Staphylococcus aureus & - & - & - & - & - & - & - & - & $34.0 \pm 0.5$ \\
\hline Pseudomonas aeruginosa & - & $10.1 \pm 0.1$ & $8.6 \pm 0.5$ & - & - & - & - & - & $28.1 \pm 0.1$ \\
\hline Escherichia coli & - & $10.6 \pm 0.1$ & $10.1 \pm 0.1$ & - & - & - & - & - & $30.3 \pm 0.2$ \\
\hline Aspergillus flavus & - & - & - & - & - & - & - & - & $34.0 \pm 0.5$ \\
\hline Aspergillus niger & - & - & $19.3 \pm 1.1$ & - & - & - & - & - & $30.0 \pm 0.5$ \\
\hline
\end{tabular}

Values are expressed as mean \pm standard deviation $(n=3)$, '-'indicates no zone of inhibition

data indicated that the compound $\mathbf{4}$ is a steroidal molecule containing a ketone group, one double bond and six methyl groups which was in complete agreement with the literature data [16] suggesting the compound as stigmast-4-en-3-one.

Compound 5 was obtained as white needle. The ${ }^{1} \mathrm{H}$ NMR spectrum of compound $\mathbf{5}$ showed three oneproton peaks in the olefinic region at $\delta 5.37,5.18$ and $5.04 \mathrm{ppm}$ and one one-proton multiplet at $\delta 3.55 \mathrm{ppm}$. The spectrum also displayed one three-proton doublet at $\delta 0.71 \mathrm{ppm}$ and one three proton singlet at $\delta 1.03$ ppm, four-three proton doublets at $\delta 0.94,0.85,0.82$ and $0.86 \mathrm{ppm}$. The ${ }^{13} \mathrm{C}$ NMR spectrum displayed an oxymethine carbon at $\delta 71.8 \mathrm{ppm}$ and four signals at $\delta$ $140.7,121.6,138.4$ and $129.2 \mathrm{ppm}$ clearly indicated the presence of one hydroxyl group and two double bonds in compound 5. This analysis and previous literature [17] were concluded recognizing this structure as $\beta$ stigmasterol.

\section{Evaluation of cytotoxicity of pure compounds}

The half-maximal inhibitory value of each compound was measured from the analysis of dose response curve. The $\mathrm{IC}_{50}$ value of each compound is summarized in Table 3. Stigmast-4-en-3-one (4) exhibited highest cytotoxic activity with $\mathrm{IC}_{50}$ value of $5.82 \mu \mathrm{g} / \mathrm{mL}$ among the tested compounds. Another compound 4hydroxybenzaldehyde (1) also presented a significant inhibition with $\mathrm{IC}_{50}$ value of $7.6 \mu \mathrm{g} / \mathrm{mL}$. 4-hydroxybenzoic acid (3) and $\beta$-stigmasterol (5) were overall ineffective in Vero cell line failed to show significant change in cell viability at the tested concentrations (Fig. 2).

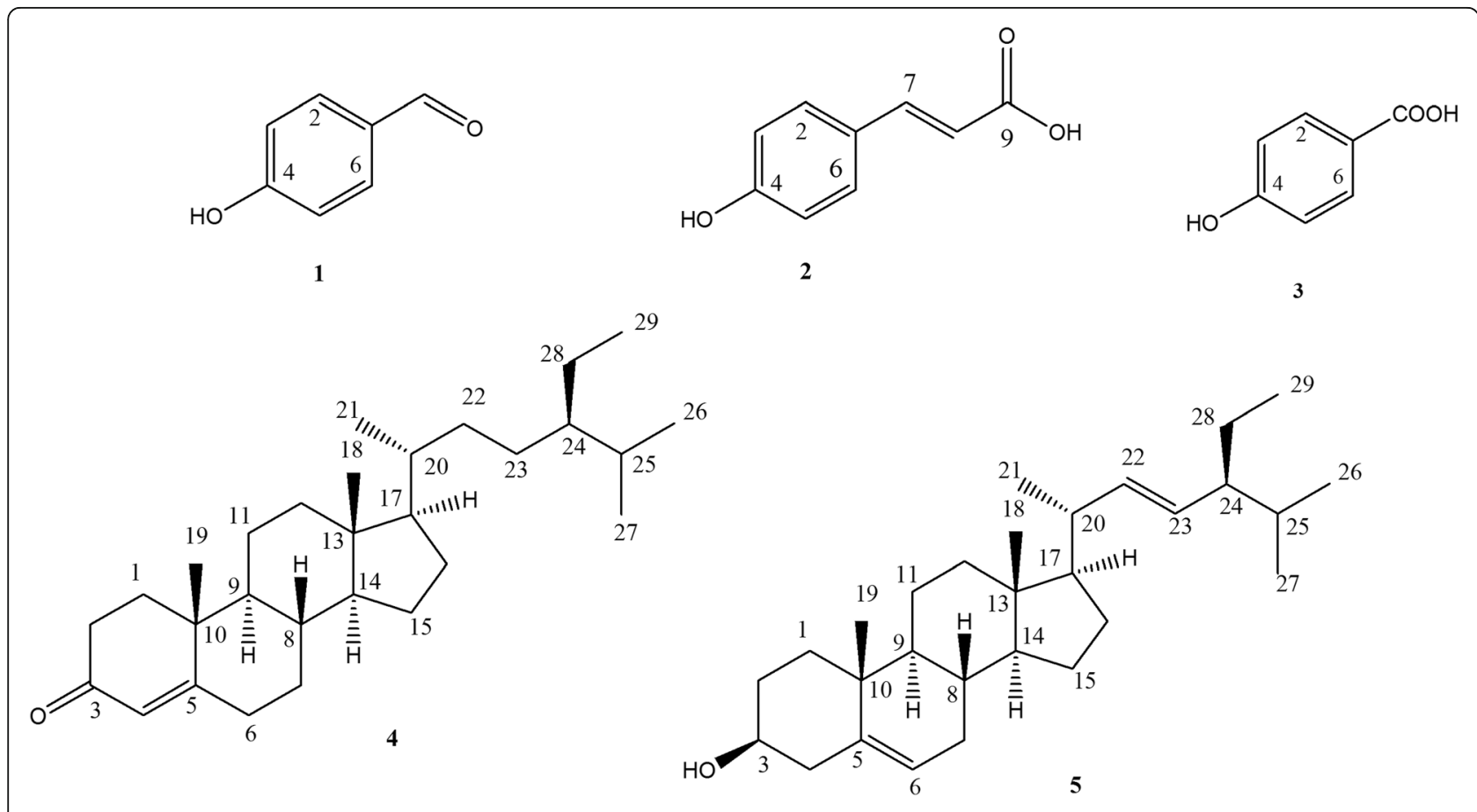

Fig. 1 Structures of 4-hydroxybenzaldehyde (1), 4-hydroxycinnamic acid (2), 4-hydroxybenzoic acid (3), stigmast-4-en-3-one (4) and $\beta$-stigmasterol (5) 
Table $3 \mid C_{50}$ value of isolated pure compounds against Vero cell line

\begin{tabular}{ll}
\hline Compounds & $\mathbf{I C}_{\mathbf{5 0}}(\boldsymbol{\mu \mathbf { g }} / \mathbf{m L})$ \\
\hline 4-Hydroxybenzaldehyde (1) & $7.60 \pm 0.66$ \\
4-Hydroxycinnamic acid (2) & $10.0 \pm 0.09$ \\
4-Hydroxybenzoic acid (3) & $38.85 \pm 0.33$ \\
Stigmast-4-en-3-one (4) & $5.82 \pm 0.66$ \\
$\beta$-stigmasterol (5) & $28.96 \pm 0.24$ \\
\hline
\end{tabular}

Values are represented as mean \pm standard deviation $(n=3)$

In Vero cell line, compound 4-hydroxycinnamic acid (2) at $5.0 \mu \mathrm{g} / \mathrm{mL}$ reduced cell viability (22.7\%) whereas compound 4-hydroxy benzoic acid (3) showed maximum cell proliferation $(88.8 \%)$ at the same concentration. It is noteworthy that these two compounds are phenolic compounds, but their bioactivity characteristics are different presumably due to their different functional groups. More investigations like applying in silico method and functional group study, animal study are required to confirm this statement.

\section{Discussion}

Polyphenols are well known for their radical quenching activity. The presence of multiple hydroxyl groups on their structure makes them able to donate single electron to the highly reactive oxygen species (ROS). These ROS are highly reactive free radicals who are developed in our body as a byproduct of natural ATP producing pathway. The damaging effects of ROS are mainly result from their ability to oxidize cell membrane and biomolecules like lipid, proteins and DNA. This ROS generated oxidative damage silently triggers the development of various degenerative diseases like diabetes, hypertension, atherosclerosis, Alzheimer's disease and cancer [18, 19]. Free radical DPPH reduces to its stable hydrazine form by accepting hydrogen/electron from potent antioxidant substances. In this assay, the VLC fractions of $T$. maxima exhibited strong radical scavenging capability which can be attributed to its isolated phenolic compounds as a positive correlation is reported between the phenolic compounds and free radical scavenging capacity [20]. Furthermore, stigmasterols are also reported to have strong antioxidant and free radical scavenging property
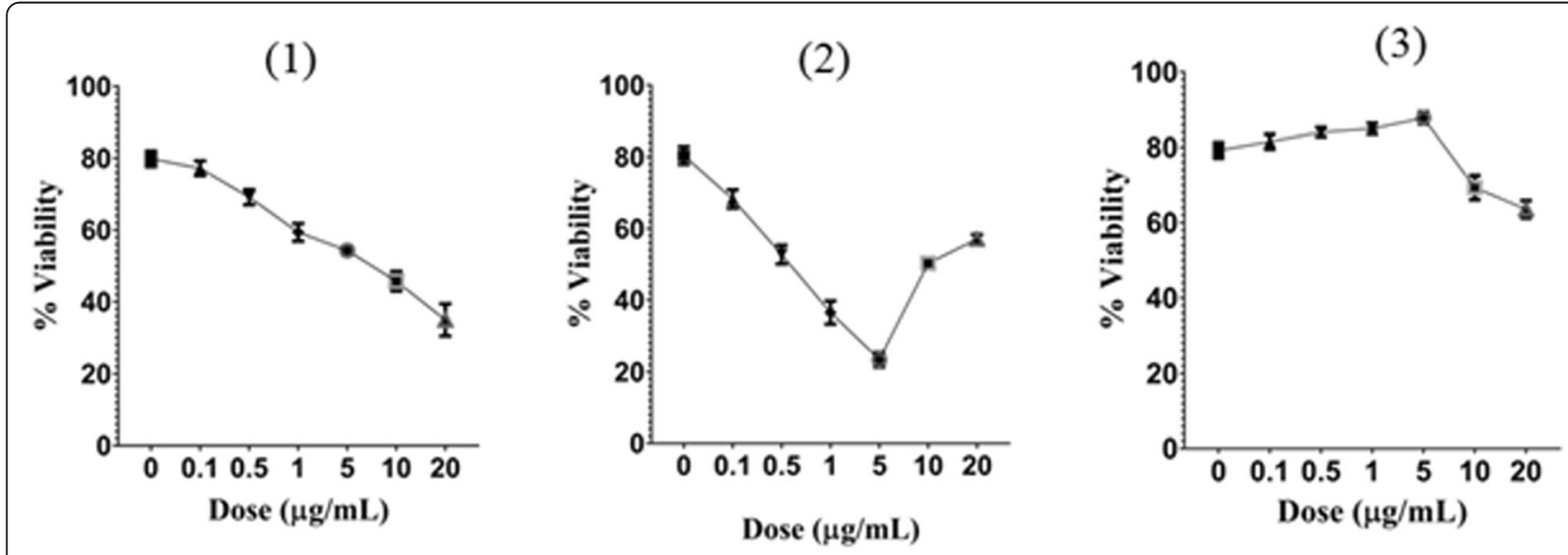

(4)

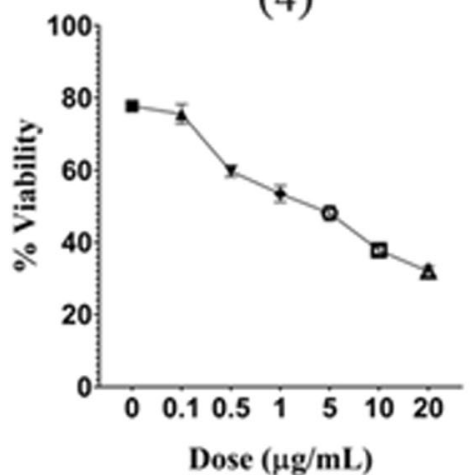

(5)

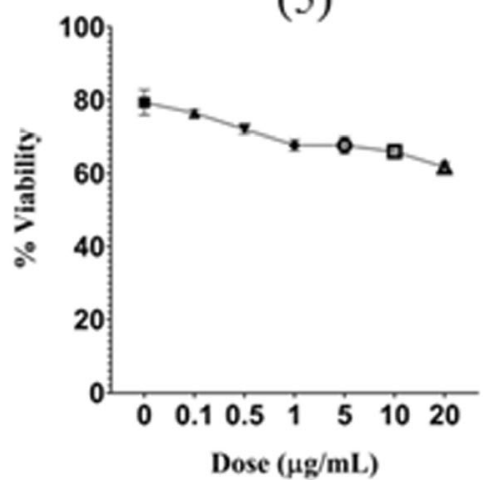

Fig. 2 Dose-response curves for the effects of isolated compounds on Vero cells. $x$-axis represents percentage of cell viability and $y$-axis represents concentration of samples of each graph 
[21]. Therefore, the strong radical scavenging activity of the VLC fractions may be attributed to the phenols and sterols present in the plant making it a potent source of antioxidants. This result is also consistent with the previous studies where presence of high amount of phenolic constituents and potent DPPH free radicals scavenging activity of this plant was reported [5, 6].

In the present study, some of the VLC fractions (F-2, F-3) showed low to moderate antibacterial activity against four strains of tested bacteria. Studies have shown that T. maxima leaf extract and its essential oils have potential antimicrobial activity which also strengthens our present findings $[6,22]$. The fraction F3 showed the maximum antifungal activity against Aspergillus flavus which make it a potential antifungal candidate. The antimicrobial properties of some individual sterols of plant origin were reported previously [23, 24]. So, the antimicrobial activities of these fractions may be related to the isolated sterols; though further studies are required to confirm this.

This study reports isolation of three phenolic compounds 4-hydroxybenzaldehyde (1), 4-hydroxycinnamic acid (2), 4-hydroxybenzoic acid (3) and two steroids stigmast-4-en-3-one (4) and $\beta$-stigmasterol (5) in which compounds 1, 2, 4 and $\mathbf{5}$ were isolated from T. maxima for the first time. Shrestha and co-investigators isolated 34 known compounds and a new compound 6 "-O-acetylorientin-2"-O- $\alpha$-L-rhamnopyranoside from this plant found in Nepal [8]. On the other hand, 21 components were identified by GC-MS from the essential oil extracted from this plant available in Southern China [22].

The highest cytotoxic activity against Vero cell line was obtained with stigmast-4-en-3-one $\left(\mathrm{IC}_{50}=5.82 \pm\right.$ $0.66 \mu \mathrm{g} / \mathrm{mL}$ ); this activity could be explained by the presence of a carbonyl group at $\mathrm{C} 3$ position in the steroidal nucleus compared to the stigmasterol $\left(\mathrm{IC}_{50}=28.96 \pm\right.$ $0.24 \mu \mathrm{g} / \mathrm{mL}$ ) having a hydroxyl group at C3 position. Another significant cytotoxic activity was observed with 4-hydroxy benzaldehyde $\left(\mathrm{IC}_{50}=7.60 \pm 0.66 \mu \mathrm{g} / \mathrm{mL}\right)$, presumably due to the presence of an aldehyde group at $\mathrm{C} 1$ position in the benzene ring whereas a carboxylic acidic group was present in other two phenolic compounds, 4-hydroxycinnamic acid $\left(\mathrm{IC}_{50}=10.0 \pm 0.09 \mu \mathrm{g} /\right.$ $\mathrm{mL})$ and 4-hydroxy benzoic acid $\left(\mathrm{IC}_{50}=38.85 \pm 0.33 \mu \mathrm{g} /\right.$ $\mathrm{mL})$. 4-Hydroxybenzaldehyde, stigmast-4-en-3-one, $\beta$ stigmasterol showed monophasic dose response curve whereas 4-hydroxycinnamic acid and 4-hydroxybenzoic acid showed bi-phasic dose response curve (Fig. 2), indicated that different mechanisms may involve for individual compound's cytotoxic activity due to their structural and functional group differences. We observed that

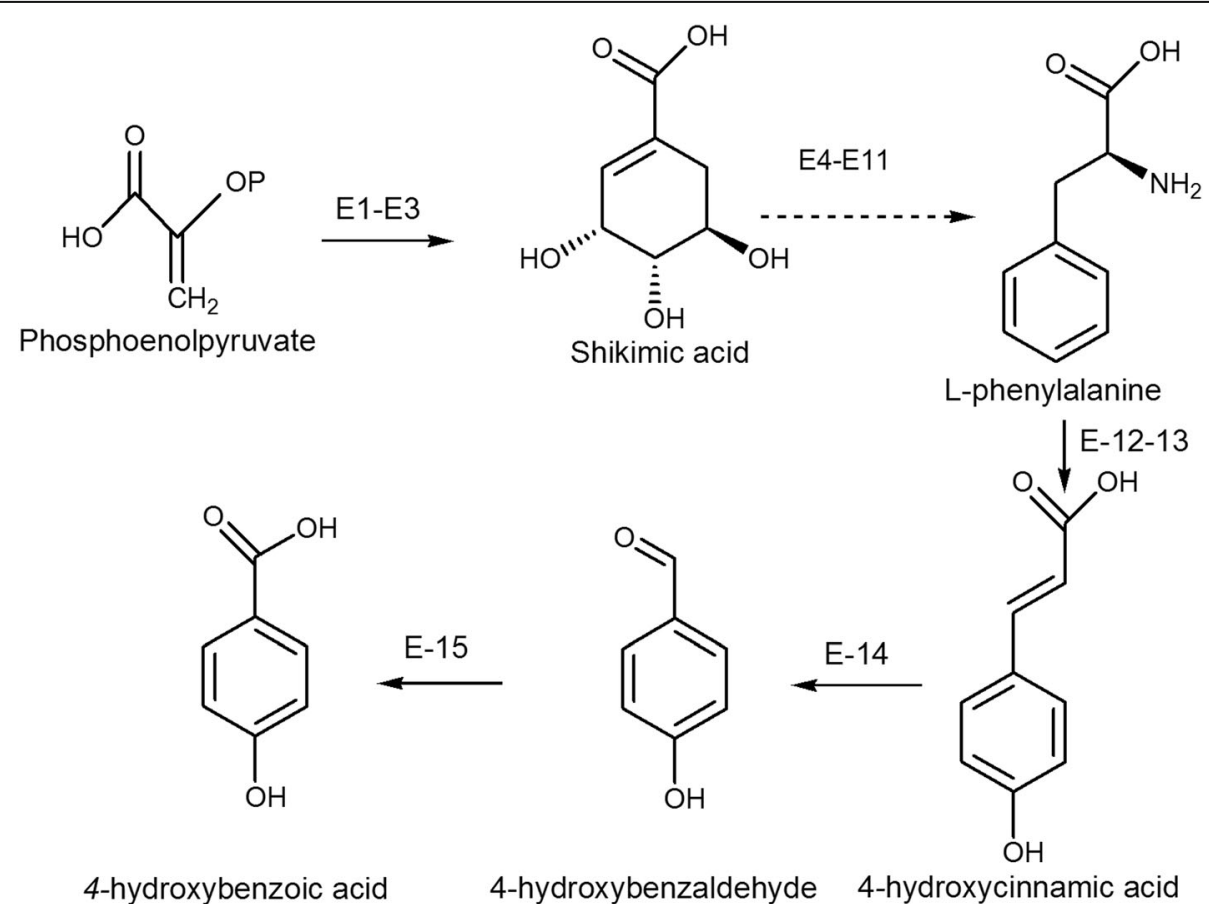

Fig. 3 Schematic representation of the possible biosynthetic pathways for 4-hydroxybenzaldehyde (1), 4-hydroxybenzoic acid (2), 4hydroxycinnamic acid (3) in Thysanolaena maxima Roxb. E1-3-deoxy-7-phosphoheptulonate synthase, E2-3-dehydroquinate synthase, E3-shikimate dehydrogenase, E4-shikimate kinase, E5-3-phosphoshikimate 1-carboxyvinyltransferase, E6-chorismate synthase, E7-chorismate mutase, E8arogenate dehydratase, E9-bifunctional aspartate aminotransferase, E10-histidinol-phosphate aminotransferase, E11-tyrosine aminotransferase, E12phenylalanine ammonia-lyase, E13- cinnamate-4-hydroxylase, E14-4-hydroxybenzaldehyde synthase, E15-4-hydroxybenzaldehyde hydroxylase 
compound 2 (4-hydroxycinnamic acid) and compound 3 (4-hydroxybenzoic acid) reduced cell viability with the increased concentration but after certain concentration cell viability increased with the higher concentration. This event suggests that at higher concentrations of compound $\mathbf{2}$ and $\mathbf{3}$, an additional pathway is activated but what this might be unknown. These two compounds were acidic among five compounds which might have influenced on the $\mathrm{pH}$ level of media that might affect cell viability. On the other hand, some macromolecules like caspase inhibitors may release in the media when used high concentration of compound $\mathbf{2}$ and 3 which may reduce cell death [25]. In the last few years it has been reported that hydroxycinnamic acid and its derivatives have potential inhibitory effects on metastasis and cancer invasion [23, 26]. Scientists have been paid great attention to elucidate the possible mechanisms involved in anticancer effects on phenolic compounds including hydroxycinnamic acids [26-28]. $\beta$-stigmasterol (5), which is commonly distributed in many medicinal plants are reported to have anti-osteoarthritic [29], antihypercholesterolemia [30], antitumor [31], hypoglycemic [32], antimutagenic [33] and anti-inflammatory activity [34]. Stigmast-4-en-3-one (4) which is a derivative of stigmasterol, showed potent hypoglycemic effect on alloxan-induced diabetic rats [32]. The incidence of stigmast-4-en-3-one is described for the first time from T. maxima and provided evidence as another source of natural hypoglycemic agent. Preliminary TLC revealed the presence of several metabolites in each of fractions F-2, F-3 and F-4. This means that these fractions might contain metabolite(s) responsible to exert antiradical or antimicrobial activity. It is also possible to assume that there may present synergistic effects of some of these compounds or individual effect of the single compound of these fractions.

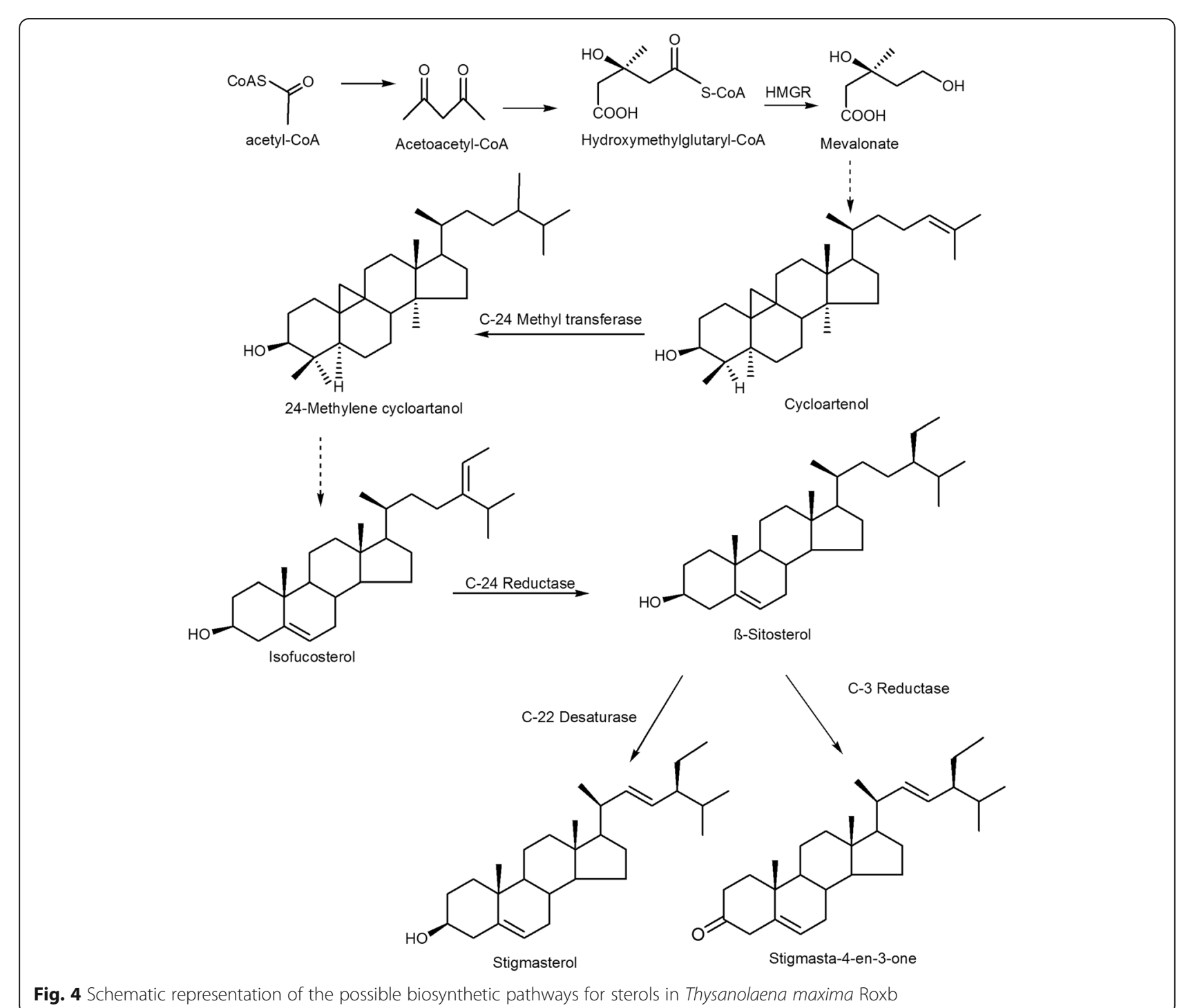


The biosynthesis of phenol compounds usually occurs at the membrane surface of the endoplasmic reticulum (ER) in plant cells [35]. Phenylalanine (L-Phe) is the main precursor for the biosynthesis of different groups of phenolic compounds such as flavonoids, coumarins, phenolic acids, tannins, lignins etc. L-Tyrosine (L-Tyr) and L-Tryptophan (L-Trp) also play an important role to produce phenolic compounds when needed by the plants [36, 37]. Several enzymes namely erythrose-4-phosphatase, phenyl alanine ammonia lyase (PAL), cinnamate-4-hydroxylase $(\mathrm{C} 4 \mathrm{H}), p$ coumarate-3-hydroxylase $(\mathrm{C} 3 \mathrm{H})$ and $o$-methyltransferase etc. are directly involved in different steps for the biosynthesis of phenolic compounds [38]. It is presumed that the biosynthesis of phenolic compounds begins by releasing an ammonia group of phenylalanine with the direct involvement of phenylalanine ammonia lyase (PAL) and this step produces trans-cinnamic acid by creating a double bond (Fig. 3). This trans-cinnamic acid is then shifted in 4-hydroxycinnamic acid with the activity of cinnamate4-hydroxylase by introducing a hydroxyl group into the aromatic ring. The 4-hydroxycinnamic acid is then converted into 4-hydroxybenzaldehyde by 4-hydroxybenzaldehyde synthase and 4-hydroxybenzaldehyde is shifted into 4-hydroxybenzoic acid with the activity of 4-hydroxybenzaldehyde hydroxylase by introducing a hydroxyl group into side chain.

It is thought that the biosynthesis of phytosterols produces in the isoprenoid pathway where C5-unit originates from the acetate-mevalonate or mevalonateindependent pathways (Fig. 4). In this biosynthetic pathway 3-hydroxy-3-methylglutaryl-CoA reductase (HMGR) plays key role to convert 3-hydroxy-3-methylglutaryl-CoA to mevalonate which is the main precursor for the biosynthesis of phytosterols [39]. A series of enzymes are involved to convert mevalonate to cycloartenol which is still unexplored. In this step cycloartenol is converted to 24-methylene cycloartenol by the activity of C24-methyl transferase. Isoflucosterol is produced from the 24-methylene cycloartenol by the involvement of different types of demethylase, reductase, transferase enzymes. Isoflucosterol is shifted to $\beta$-sitosterol with the activity of C-24 reductase. $\beta$-sitosterol is converted to stigmasterol when $\mathrm{C}$ 24 reductase is involved and stigmasta-4-en-3-one is originated when $\mathrm{C}-3$ reductase is involved [40].

\section{Conclusion}

This study is suggestive that T. maxima is a rich source of different phenolic and steroid compounds which can be used as a source of antioxidant, antimicrobial and cytotoxic agents in the development of new therapeutic agents. Further work on isolation of compounds with bioactivities is on progress and will be reported in due course.

\section{Acknowledgements}

Authors are grateful to Pharmaceutical Science Research Division, BCSIR Laboratories Dhaka for providing with the necessary laboratory and instrumental facilities and also for all the chemical and reagent supports.

\section{Authors' contributions}

All authors have participated sufficiently in the work to take public responsibility for appropriate portions of the content of the manuscript. Author MHS conceived the presented research project and supervised all the work along with FA, SR and $\mathrm{CMH}$. Author $\mathrm{NH}$, SRR managed the literature study. Author NH, SRR, SS and FM performed the experimental work as well as performed the statistical analysis. Author NH wrote the first draft of the manuscript which was corrected by FA and SS. Authors FA, SR, and MHS finalized the final drafting of the manuscript. All authors read and approved the final manuscript.

\section{Funding}

Authors receive no fund for the research work.

\section{Availability of data and materials}

The datasets used and/or analysed during the current study are mostly included in the submitted manuscript. Any other information will be available from the corresponding author upon request.

Ethics approval and consent to participate

Not applicable.

\section{Consent for publication}

Not applicable.

\section{Competing interests}

The authors declare that they have no competing interests.

\section{Author details}

${ }^{1}$ Department of Pharmacy, East West University, Aftabnagar, Dhaka 1212, Bangladesh. ${ }^{2}$ Pharmaceutical Sciences Research Division, BCSIR Laboratories Dhaka, Bangladesh Council of Scientific and Industrial Research (BCSIR), Dr. Qudrat-I-Khuda Road, Dhanmondi, Dhaka 1205, Bangladesh. ${ }^{3}$ Department of Pharmacy, Jahangirnagar University, Savar, Dhaka 1342, Bangladesh.

${ }^{4}$ Department of Pharmaceutical Chemistry, Faculty of Pharmacy, University of Dhaka, Dhaka 1000, Bangladesh.

Received: 14 February 2020 Accepted: 10 November 2020

Published online: 11 December 2020

\section{References}

1. Hynniewta SR, Kumar Y. Herbal remedies among the Khasi traditional healers and village folks in Meghalaya. Indian J Tradit Knowl. 2008;7:581-6 http://nopr.niscair.res.in/handle/123456789/2383.

2. Rout J, Sajem AL, Nath M. Medicinal plants of north Cachar hills district of Assam used by the Dimasa tribe. Indian J Tradit Knowl. 2012;11:520-7 http://nopr.niscair.res.in/handle/123456789/14395.

3. Tiwary BK, Bihani S, Kumar A, Chakraborty R, Ghosh R. In vitro cytotoxic activity of ethno-pharmacological important plants of Darjeeling district of West Bengal against different human cancer cell lines. BMC Complement Altern Med. 2015;15:1-10.

4. Rahmatullah M, Ayman U, Akter F, Sarker M, Sifa R, Sarker B, Chyti HN, Jahan $\mathrm{Fl}$, Chowdhury MH, Chowdhury SA. Medicinal formulations of a Kanda tribal healer - a tribe on the verge of disappearance in Bangladesh. Afr J Tradit Complement Altern Med. 2012;10:213-22. https://doi.org/10.4314/ajtcam. v10i2.5 https://www.ncbi.n/m.nih.gov/pubmed/24146444.

5. Gnanaraj C, Haque ATME, lqbal M. The chemopreventive effects of Thysanolaena latifolia against carbon tetrachloride (CCl4)-induced oxidative stress in rats. J Exp Integr Med. 2012;2:345-55. https://doi.org/10.5455/jeim. 030912.or.045 https://www.researchgate.net/publication/265059034.

6. Subba B, Basnet P. Antimicrobial and antioxidant activity of some indigenous plants of Nepal. J Pharmacogn Phytochem. 2014;3:62-7 http:// www. phytojournal.com/archives/?year=2014\&vol=3\&issue=1\&Articleld=312.

7. Hoque N, Sohrab MH, Debnath T, Rana MS. Antioxidant, antibacterial and cytotoxic activities of various extracts of Thysanolaena maxima (Roxb.) kuntze available in Chittagong hill tracts of Bangladesh. Int J Pharm Pharm 
Sci. 2016;8:168-72 https://innovareacademics.in/journals/index.php/ijpps/ article/view/11490

8. Shrestha S, Park JH, Cho JG, Lee DY, Jeong RH, Song MC, Cho SK, Lee DS, Baek NI. Phytochemical constituents from the florets of tiger grass Thysanolaena latifolia from Nepal. J Asian Nat Prod Res. 2016;18:206-13. https://doi.org/10.1080/10286020.2015.1062757.

9. Braca A, De Tommasi N, Di Bari L, Pizza C, Politi M, Morelli I. Antioxidant principles from Bauhinia terapotensis. J Nat Prod. 2001;64:892-5. https://doi. org/10.1021/np0100845 https://pubs.acs.org/doi/abs/10.1021/np0100845.

10. Khan N, Afroz F, Begum MN, Rony SR, Sharmin S, Moni F, Hasan CM, Shaha K, Sohrab MH. Endophytic Fusarium solani: a rich source of cytotoxic and antimicrobial napthoquinone and aza-anthraquinone derivatives. Toxicol Rep. 2018;5:970-6. https://doi.org/10.1016/j.toxrep.2018.08.016 https://www. ncbi.nlm.nih.gov/pubmed/30294556/.

11. Strober W. Trypan blue exclusion test of cell viability. Curr Protoc Immunol. 2001. https://doi.org/10.1002/0471142735.ima03bs111 https://www.ncbi.nlm. nih.gov/pubmed/18432654.

12. Wilson CH, Ali ES, Scrimgeour N, Martin AM, Hua J, Tallis GA, Rychkov GY, Barritt GJ. Steatosis inhibits liver cell store-operated $\mathrm{Ca}^{2+}$ entry and reduces $\mathrm{ER} \mathrm{Ca}^{2+}$ through a protein kinase C-dependent mechanism. Biochem J. 2015;466:379-90. https://doi.org/10.1042/BJ20140881 https://www.ncbi.nlm. nih.gov/pubmed/25422863.

13. Berry MN, Barritt GJ, Edwards AM. Isolated hepatocytes: preparation, properties and applications. New York: Elsevier Science; 1991. https://www. elsevier.com/books/978-0-444-81302-2.

14. Nguyen DH, Zhao BT, Le DD, Kim KY, Kim YH, Yoon YH, Ko JY, Woo KS, Woo $\mathrm{MH}$. Phenolic constituents and their anti-inflammatory activity from Echinochloa utilis grains. Nat Prod Sci. 2016;22:140-5. https://doi.org/10. 20307/nps.2016.22.2.140 https://www.researchgate.net/publication/3054615 09.

15. Yi B, Hu L, Mei W, Zhou K, Wang H, Luo Y, Wei X, Dai H. Antioxidant phenolic compounds of cassava (Manihot esculenta) from Hainan. Molecules. 2011;16:10157-67. https://doi.org/10.3390/molecules161210157 https://www.ncbi.nlm.nih.gov/pubmed/22157579.

16. DellaGreca M, Monaco P, Previtera L. Stigmasterols from Typha latifolia. J Nat Prod. 1990:53:1430-5. https://doi.org/10.1021/np50072a005.

17. Ahmed Y, Rahman S, Akhtar P, Islam F, Rahman M, Yaako Z. Isolation of steroids from $n$-hexane extract of the leaves of Saurauia roxburghii. Int Food Res J. 2013;20:2939-43 https://www.researchgate.net/publication/25996 9879.

18. Liao K, Yin M. Individual and combined antioxidant effects of seven phenolic agents in human erythrocyte membrane ghosts and phosphatidylcholine liposome system: the importance of the partition coefficient. J Agric Food Chem. 2000;48:2266-70. https://doi.org/10.1021/ jf990946w https://www.ncbi.nlm.nih.gov/pubmed/10888534.

19. Iqbal E, Salim KA, Lim LB. Phytochemical screening, total phenolics and antioxidant activities of bark and leaf extracts of Goniothalamus velutinus (Airy Shaw) from Brunei Darussalam. J King Saud Univ Sci. 2015;27:224-32. https://doi.org/10.1016/j.jksus.2015.02.003 https://www.researchgate.net/ publication/272297904

20. McDonald S, Prenzler PD, Antolovich M, Robards K. Phenolic content and antioxidant activity of olive extracts. Food Chem. 2001;73:73-84. https://doi. org/10.1016/S0308-8146(00)00288-0

21. Kaur N, Chaudhary J, Jain A, Kishore L. Stigmasterol: a comprehensive review. Int J Pharm Sci Res. 2011;2:2259-65. https://doi.org/10.13040/IJPSR. 0975-8232.2(9).2259-65.

22. Li R, Hu HB, Li XF, Zhang P, Xu YK, Yang JJ, Wang YF. Essential oils composition and bioactivities of two species leaves used as packaging materials in Xishuangbanna, China. Food Control. 2015;51:9-14.

23. Kuete V, Nguemeving JR, Beng VP, Azebaze AG, Etoa FX, Meyer M, Bodo B, Nkengfack AE. Antimicrobial activity of the methanolic extracts and compounds from Vismia laurentii De Wild (Guttiferae). J Ethnopharmacol. 2007;109:372-9. https://doi.org/10.1016/j.jep.2006.07.044 https://www.ncbi. nlm.nih.gov/pubmed/16971076.

24. Djoukeng JD, Abou-Mansour E, Tabacchi R, Tapondjou AL, Bouda H, Lonts D. Antibacterial triterpenes from Syzygium guineense (Myrtaceae). Ethnopharmacol. 2005;101:283-6. https://doi.org/10.1016/j.jep.2005.05.008 https://www.researchgate.net/publication/7775047.

25. Quesney S, Marvel J, Marc A, Gerdil C, Meignier B. Characterization of Vero cell growth and death in bioreactor with serum-containing and serum-free media. Cytotechnology. 2001;35:115-25.
26. Weng CJ, Yen GC. Chemo preventive effects of dietary phytochemicals against cancer invasion and metastasis: phenolic acids, monophenol, polyphenol, and their derivatives. Cancer Treat Rev. 2012;38:76-87. https:// doi.org/10.1016/j.ctrv.2011.03.001 https://www.ncbi.nlm.nih.gov/ pubmed/21481535.

27. Puangpraphant S, Berhow MA, Vermillion K, Potts G, Gonzalez de Mejia E. Dicaffeoylquinic acids in Yerba mate (llex paraguariensis St. Hilaire) inhibit $\mathrm{NF}-\mathrm{KB}$ nucleus translocation in macrophages and induce apoptosis by activating caspases-8 and-3 in human colon cancer cells. Mol Nutr Food Res. 2011;55:1509-22. https://doi.org/10.1002/mnfr.201100128 https://www. ncbi.nlm.nih.gov/pubmed/21656672.

28. Rosa LS, Silva NJ, Soares NC, Monteiro MC, Teodoro AJ. Anticancer properties of phenolic acids in colon cancer - a review. J Food Sci Nutr. 2016;6:10-4172. https://doi.org/10.4172/2155-9600.1000468 https:/www. longdom.org/abstract/anticancer-properties-of-phenolic-acids-in-coloncancer-a-review-35403.html.

29. Gabay O, Sanchez C, Salvat C, Chevy F, Breton M, Nourissat G, Wolf C, Jacques C, Berenbaum F. Stigmasterol: a phytosterol with potential antiosteoarthritic properties. Osteoarthr Cartilage. 2010;18:106-16 https:// www.sciencedirect.com/science/article/pii/S1063458409002179.

30. Chandler RF, Hooper SN, Ismail A. Antihypercholesterolemic studies with sterols: beta-sitosterol and stigmasterol. J Pharm Sci. 1979;68:245-7 https:// www.sciencedirect.com/science/article/abs/pii/S0022354915424621.

31. Kasahara Y, Kumaki K, Katagiri S, Yasukawa K, Yamanouchi S, Takido M, Akihisa T, Tamura T. Carthami flos extract and its component, stigmasterol, inhibit tumour promotion in mouse skin two stage carcinogenesis. Phytother Res. 1994;8:327-31. https://doi.org/10.1002/ptr.2650080603.

32. Jamaluddin F, Mohamed S, Lajis MN. Hypoglycaemic effect of Parkia speciosa seeds due to the synergistic action of $\beta$-sitosterol and stigmasterol. Food Chem. 1994;49:339-45. https://doi.org/10.1016/0308-8146(94)90002-7 https://www.sciencedirect.com/science/article/pii/0308814694900027.

33. Jae-Chul L, Jong Hee P, Milos B, Alexander K, Yeong-Hwan H, Byung-Soo K, et al. Antimutagenic constituents from the thorns of Gleditsia sinensis. Chem Pharm Bull. 2005;53:561-4.

34. Garcia MD, Saenz MT, Gomez MA, Fernandez MA. Topical anti-inflammatory activity of phytosterols isolated from Eryngium foetidum on chronic and acute inflammation models. Phytother Res. 1999;13:78-80. https://doi.org/ 10.1002/(SICI) 1099-1573(199902)13:1<78::AID-PTR384>3.0.CO;2-F https:// onlinelibrary.wiley.com/doi/pdf/10.1002/(SICI) 1099-1573(199902).

35. Shahidi $F$, Yeo J. Bioactivities of phenolics by focusing on suppression of chronic diseases: a review. Int J Mol Sci. 2018;19:1573. https:/doi.org/10.3390/ ijms19061573 https://www.ncbi.nlm.nih.gov/pmc/articles/PMC6032343/.

36. Weaver LM, Herrmann KM. Dynamics of the shikimate pathway in plants. Trends Plant Sci. 1997;2:346-51. https://doi.org/10.1016/S13601385(97)84622-5.

37. Jiang X, Liu Y, Li W, Zhao L, Meng F, Wang Y, Tan H, Yang H, Wei C, Wan X, Gao L, Xia T. Tissue-specific, development-dependent phenolic compounds accumulation profile and gene expression pattern in tea plant (Camellia sinensis). PLoS One. 2013;8:e62315. https://doi.org/10. 1371/journal.pone.0062315.

38. Shahidi F, Naczk M. Phenolics in food and nutraceuticals. Boca Raton: CRC press; 2003. ISBN 978036739509.

39. Harker M, Holmberg N, Clayton JC, Gibbard CL, Wallace AD, Rawlins S, Hellyer SA, Lanot A, Safford R. Enhancement of seed phytosterol levels by expression of an $\mathrm{N}$-terminal truncated Hevea brasiliensis (rubber tree) 3hydroxy-3-methylglutaryl-CoA reductase. Plant Biotechnol J. 2003;1:113-21. https://doi.org/10.1046/j.1467-7652.2003.00011.x https://www.researchgate. net/publication/6650929.

40. Seki H, Ohyama K, Nishizawa T, Yoshida S, Muranaka T. The "all-in-one" rol-type binary vectors as a tool for functional genomic studies using hairy roots. Plant Biotechnol-Nar. 2008;25:347-55. https://doi.org/10.5511/plantbiotechnology.25. 347 https:/www.researchgate.net/publication/271887385.

\section{Publisher's Note}

Springer Nature remains neutral with regard to jurisdictional claims in published maps and institutional affiliations. 